\title{
THE PRESENT STATUS OF DOUBLE-CRESTED CORMORANT COLONIES IN MANITOBA
}

\section{by Kees Vermeer, Canadian Wildlife Service, Edmonton}

McLeod and Bondar (1953) made a thorough ineld survey of nesting colonies of Double-crested Cormorants, Phalacrocorax auritus, at Lake Winnipegosis, Manitoba. They counted 9862 , 5949, and 4656 nests in 1945 , 1950 and 1951 respectively. Although they found that the cormorant diet was composed of only 7.2 per cent commercial fish, they nevertheless thought the number of cormorants to be excessive, and eggs and young were destroyed on a large scale in order to reduce the population.
The objective of my study was to compare the present breeding population at Lake Winnipegosis with that observed by McLeod and Bondar 18 years ago, as well as to investigate the distribution and size of all colonies in Manitoba.

\section{Methods}

The colonies were surveyed by float plane in 1969. In order to curb costs of flying, nest counts of many small colonies were done from the air. A few, and probably small, colonies may have

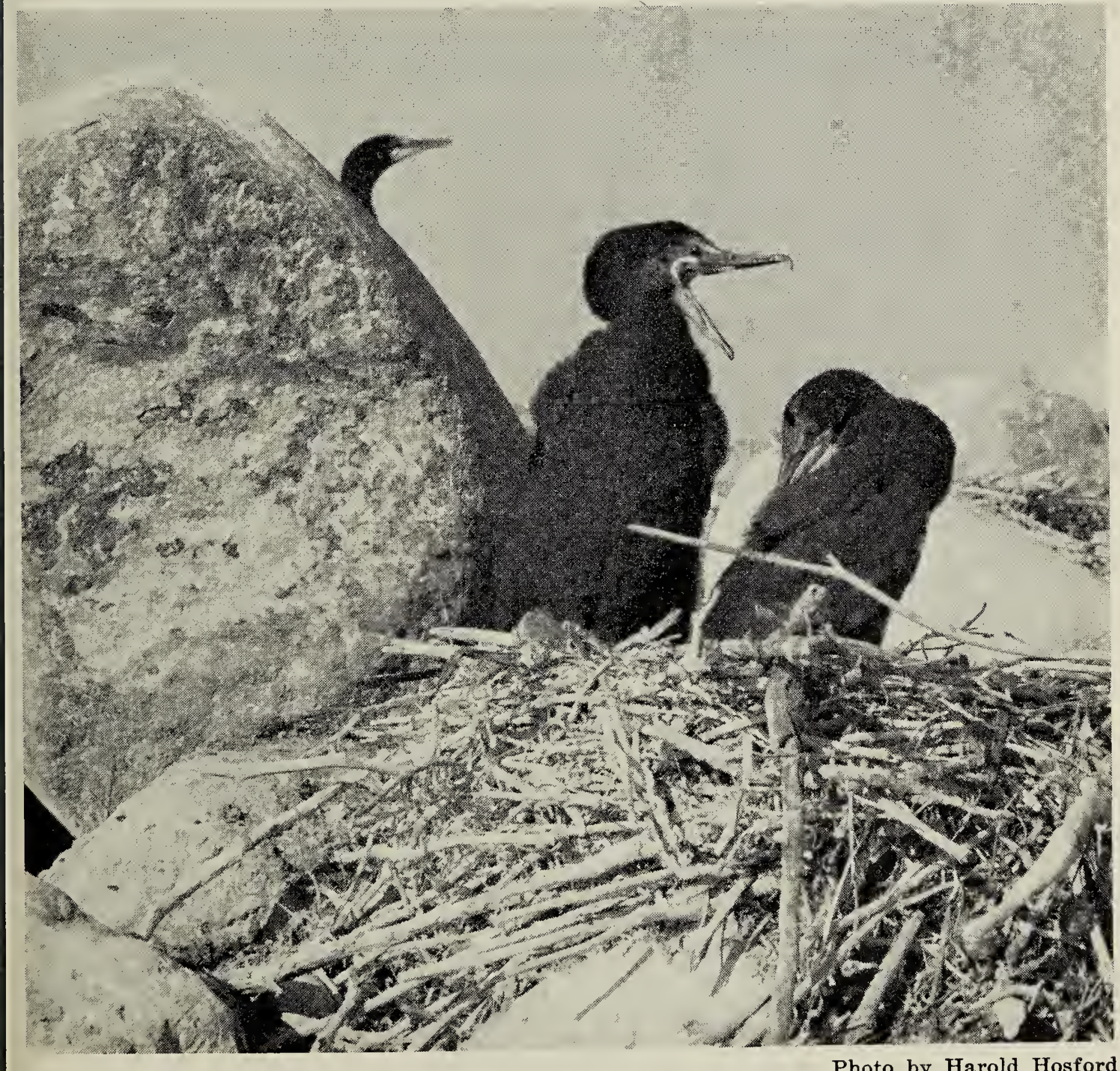

Young cormorants on island in West Shoal Lake, Manitoba, 1959. 
been missed as the survey was not exhaustive. The survey was made when the eggs started to hatch to insure a maximum count of nests. The visits were made as quickly as possible and in mild weather to keep effects of human intrusion to a minimum.

\section{Results and discussion}

Figure 1 depicts the active nesting colonies of Double-crested Cormorants in Manitoba in 1969. The numbered colonies in Figure 1 are identified in Table 1. The total was 4772 nests. As the laying season of cormorants in the prairie provinces can last two and a half months (Vermeer, in press), an unknown number of clutches, initial as well as replacement, were probably initiated after the counts. Considering that late initial clutches plus a few, and probably small, colonies may have been missed, the total breeding population in Manitoba was estimated to consist of 10,000 birds. From Table 1 it can be seen that Lake Winnipegosis with 1403 nests had the largest breeding population in Manitoba. As McLeod and Bondar (1953) counted 4656 nests there in 1951, it can be seen that the population has declined to less than one-third over the past 18 years. The destruction of eggs and young by these authors may have caused a decline in the years immediately after. But the breeding population, in the

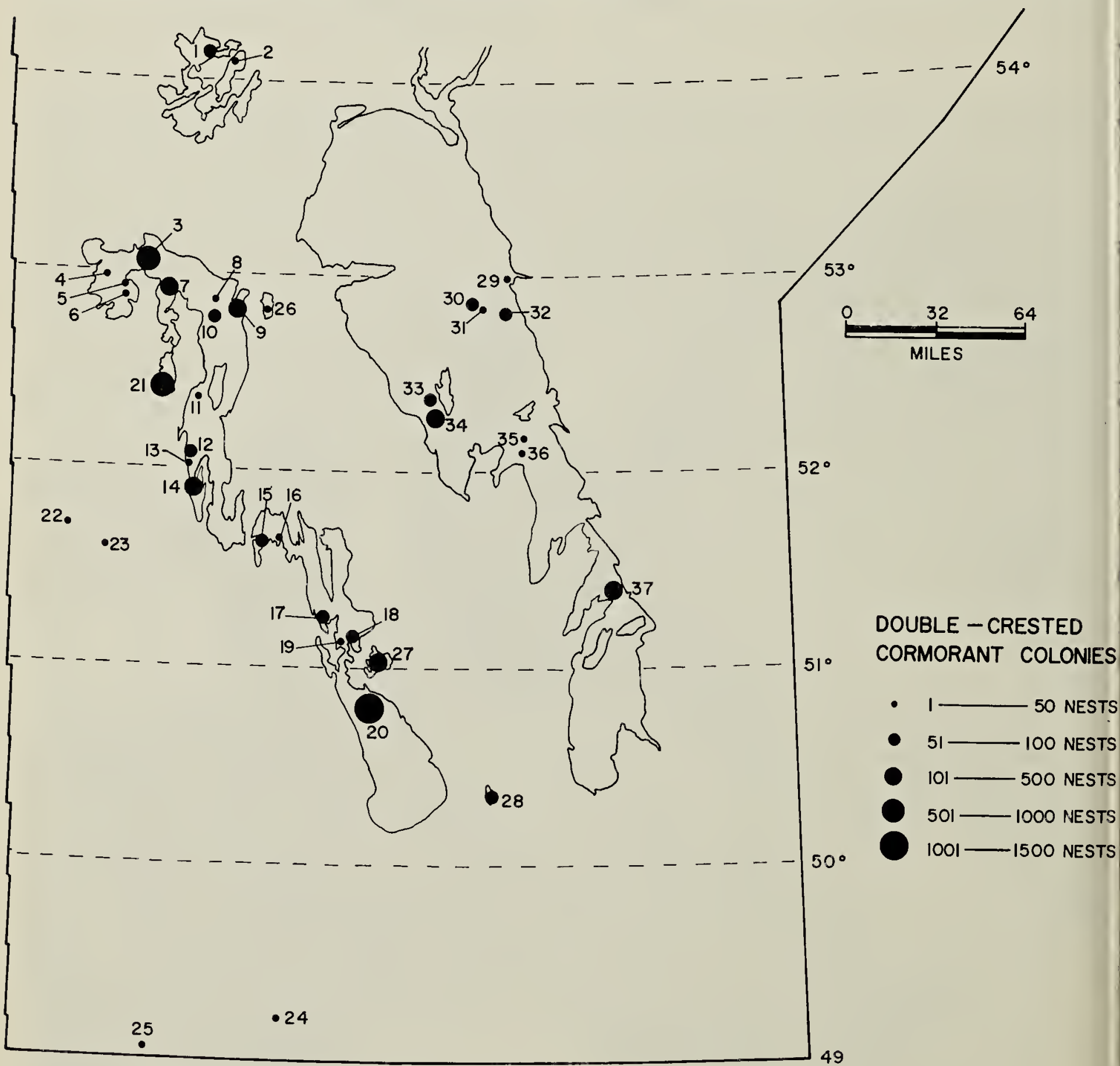

Figure 1. Distribution and size of Double-crested Cormorant colonies in Manitoba in 1969. 
Table 1. Number of nests and location of active colonies of Double-crested Cormorants in Manitoba

\section{Colony Location}

1. Moose Lake -2 reefs

2. Talbot Lake -1 reef

Lake Winnipegosis

3. Reef east of Spruce Isl.

4. Reef east of Rowan Isl.

5. Vance Reef

6. Reef northwest of Mason Isl.

7. Reef west of Whisky Jack Isl.

8. Reef north of Cormorant Isl.

9. Reef southeast of Denbeigh Pt.

10. Reef north of Pemmican Isl.

11. Reef south of Sealey Isl.

12. Reef northeast of Gamblers Pt.

13. Reef northeast of Gamblers Pt.

14. Reef south of Coleman Isl.

Lake Manitoba

15. Reef south of South Twin Isl.

16. Reef northwest of Little Sandy Pt.

17. Reef northwest of Reykjavik

18. Reef north of Richard Pt.

19. Reef west of Richard Pt.

20. Island southwest of Duck Isl.

21. Pelican Lake -3 islands

Duck Mountain Provincial Park

22. Edge of unnamed pond

23. Edge of unnamed pond

24. Edge of Rock Lake

25. Sharpe Lake -1 island

26. Kawinaw Lake -1 island

27. Dog Lake - 1 reef

28. East Shoal Lake -- 1 reef

Lake Winnipeg

29. Reef north of Poplar Pt.

30. Reef northwest of George Isl.

31. Reef northwest of Greorge Isl.

32. Reef southeast of George Isl.

33. Reef west of Reindeer Isl .

34. St. Martin Isl. -3 reefs

35. Reef southeast of Johns Isl.

36. Reef west of Nut Isl.

37. Pipestone Rock -3 reefs
Latitude Longitude No. of nests

$\begin{array}{rrrrr}54^{\circ} & 09^{\prime} \mathrm{N} & 100^{\circ} & 04^{\prime} \mathrm{W} & 58^{*} \\ 54^{\circ} & 07^{\prime} \mathrm{N} & 99^{\circ} & 53^{\prime} \mathrm{W} & 28^{*}\end{array}$

$53^{\circ} 04^{\prime} \mathrm{N}$

$100^{\circ} 30^{\prime} \mathrm{W}$

$645^{*}$

$52^{\circ} 58^{\prime} \mathrm{N} \quad 100^{\circ} 53^{\prime} \mathrm{W}$

40

$52^{\circ} 55^{\prime} \mathrm{N}$

$100^{\circ} 44^{\prime} \mathrm{W}$

10

$52^{\circ} 53^{\prime} \mathrm{N}$

$100^{\circ} 43^{\prime} \mathrm{W}$

12

$52^{\circ} 55^{\prime} \mathrm{N}$

$100^{\circ} 20^{\prime} \mathrm{W}$

155 *

$52^{\circ} 52^{\prime} \mathrm{N}$

$99^{\circ} 56^{\prime} \mathrm{W}$

40

$52^{\circ} 49^{\prime} \mathrm{N}$

$99^{\circ} 46^{\prime} \mathrm{W}$

$171 *$

$52^{\circ} 47^{\prime} \mathrm{W}$

$100^{\circ} 00^{\prime} \mathrm{W}$

$97 *$

$52^{\circ} 20^{\prime} \mathrm{N}$

$100^{\circ} 05^{\prime} \mathrm{W}$

$100^{\circ} 07^{\prime} \mathrm{W}$

$100^{\circ} 08^{\prime} \mathrm{W}$

$52^{\circ} 03^{\prime} \mathrm{N}$

$100^{\circ} 03^{\prime} \mathrm{W}$

8

ca 60

$51^{\circ} 55^{\prime} \mathrm{N}$

$51^{\circ} 38^{\prime} \mathrm{N}$

$99^{\circ} 28^{\prime} \mathrm{W}$

$51^{\circ} 39^{\prime} \mathrm{N}$

$99^{\circ} 20^{\prime} \mathrm{W}$

30

$51^{\circ} 15^{\prime} \mathrm{N}$

$98^{\circ} 59^{\prime} \mathrm{W}$

$98^{\circ} \quad 45^{\prime} \mathrm{W}$

$98^{\circ} \quad 48^{\prime} \mathrm{W}$

$98^{\circ} 37^{\prime} \mathrm{W}$

$135^{*}$

$51^{\circ} 08^{\prime} \mathrm{N}$

$50^{\circ} 49^{\prime} \mathrm{N}$

$52^{\circ} 25^{\prime} \mathrm{N}$

$100^{\circ} 20^{\prime} \mathrm{W}$

$79^{*}$

8

$87 *$

88*

3

$1010^{*}$

802 *

$51^{\circ} 46^{\prime} \mathrm{N}$

$101^{\circ} 08^{\prime} \mathrm{W}$

10

$51^{\circ} 37^{\prime} \mathrm{N}$

$100^{\circ} 45^{\prime} \mathrm{W}$

25

$49^{\circ} 13^{\prime} \mathrm{N}$

$99^{\circ} 15^{\prime} \mathrm{W}$

$100^{\circ} 20^{\prime} \mathrm{W}$

$99^{\circ} 29^{\prime} \mathrm{W}$

$98^{\circ} 30^{\prime} \mathrm{W}$

$97^{\circ} 36^{\prime} \mathrm{W}$

$52^{\circ} 22^{\prime} \mathrm{N}$

$52^{\circ} 59 \mathrm{~N}^{\prime}$

$97^{\circ} 32^{\prime} \mathrm{W}$

$97^{\circ} 43^{\prime} \mathrm{W}$

$97^{\circ} 40^{\prime} \mathrm{W}$

$97^{\circ} 30^{\prime} \mathrm{W}$

$98^{\circ} 04^{\prime} \mathrm{W}$

$98^{\circ} 01^{\prime} \mathrm{W}$

$97^{\circ} 20^{\prime} \mathrm{W}$

$97^{\circ} 22^{\prime} \mathrm{W}$

$96^{\circ} 32^{\prime} \mathrm{W}$

$51^{\circ} 03^{\prime} \mathrm{N}$ ca 60

\section{3}

18

$4^{*}$

$175^{*}$

5

ca 75

7

ca 70

$72^{*}$

$407^{*}$

7

8

$260^{*}$

\section{Total number of nests}

4772

* Nest counts made on the ground (all other counts were made from the air).

December, 1969 
absence of further harassment, should have recovered by recruitment and immigration over an 18-year period. The authors reported that prior to and during their survey fishermen and lumbermen also destroyed the eggs in several colonies. Large-scale destruction of cormorant eggs by fishermen occurred at Suggi Lake, Saskatchewan, 105 miles northwest of Lake Winnipegosis, as recently as 1964 (Carson, 1966). Since many cases of nest destruction undoubtedly go unreported, human disturbance may be a major cause behind the decline at Lake Winnipegosis.

Nesting colonies reported by McLeod and Bondar at Lake Atikameg and by Lewis $(1929,1931)$ at Chitek Lake, Pelican River and Cedar Lake were no longer present in 1969. The nesting site at Cedar Lake has presumably been flooded out since the construction of the Grand Rapids Dam.

In all colonies, except four, cormorants nested on the ground of mostly small, treeless islands and reefs. Cormorants nested in dead trees on a partly flooded island in Sharpe Lake. At two ponds in Duck Mountain Provincial Park and at Rock Lake, the birds nested in living trees along the lake shore. No bare islands or reefs appeared to be available for nesting purposes at those four locations. Cormorants nested in trees along the lake shore after their former nesting island became part of the mainland at Miquelon Lake, Alberta (R. Lister, pers. comm.). California Gulls, Larus californicus, nesting on islands separated from the mainland by very shallow water channels in Alberta have been observed to be subject to extensive predation by coyotes, Canis latrans (Vermeer, 1967). The preference of cormorants for nesting on islands may be a mechanism directed against mammalian predation. From the observation of nesting colonies in shallow water such as Kawinaw Lake and East Shoal Lake, where fish are scarce (Dr. K. H. Doan, Chief Provincial Fishery Biologist, Manitoba, pers. comm.), close proximity of fish can be of less importance than an inaccessible nesting site. Besides availability of fish, inaccessibility of nesting sites, and human disturbance, another factor affecting the distribution of nesting colonies appears to be the fluctuation of water levels. Several colonies in Saskatchewan disappeared as a result of flooding and falling lake levels (Houston, 1962).

\section{Summary}

On the basis of a count of 4772 nests, the total breeding population of Double-crested Cormorants in Manitoba in 1969 was estimated to consist of 10,000 birds. Lake Winnipegosis, with 1403 nests, had the largest breeding colony. The population at that lake has declined to less than onethird over the past 18 years. In all colonies in Manitoba, except four, cormorants nested on the ground of mostly small, treeless islands and reefs.

\section{Acknowledgments}

The assistance of Dr. G. Adams and Mr. D. Hatch, Canadian Wildlife Service, in locating nesting colonies, is much appreciated.

\section{LITERATURE CITED}

Carson, R. D. 1966. Destruction of colonial birds on an island on Suggi Lake. Blue Jay, $24: 96-97$.

Houston, C. S. 1962. Hazards faced by colonial birds. Blue Jay, 20:74-77.

Lewis, H. F. 1929. The natural history of the Double-crested Cormorant (Phalacrocorax auritus auritus (Lesson)). Published Ph.D. thesis, Ottawa. 94 pp.

Lewis, H. F. 1931. Additional information concerning the Double-crested Cormorant (Phalacrocorax auritus auritus (Lesson)). Auk, $48: 207-214$.

McLeod, J. A., and G. F. Bondar, 1953. A brief study of the Double-crested Cormorant on Lake Winn1pegosis. Can. Field--Nat., 67:1-11.

Vermeer, K. 1967. A study of two species of gulls, Larus californicus and L. delawarensis breeding in an inland habitat. Unpublished Ph.D. thesis, University of Alberta, Edmonton, $128 \mathrm{pp}$.

Vermeer, K. Some aspects of the breeding chronology of Double-crested Cormorants at Lake Newell, Alberta in 1968. Murrelet, in press. 